\title{
Stock Price Reaction to Announcements of Right Issues and Debenture Issues: Evidence from Colombo Stock Exchange
}

\author{
By
}

\section{Udani Chathurika Edirisinghe}

A thesis submitted to the Umiversity of Smi Itaycenvardenepura in partial fulfillmemt of the requirrememtss for the Degree of Master of Science ium Mampagementom331 it January 2013 
The work described in this thesis was carried out by me under the supervision of Dr. P.D. Nimal and a report on this has not been submitted in whole or in part to any university or any other institution for another Degree/ Diploma

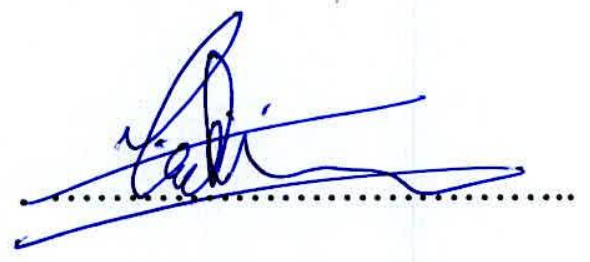

U. Chathurika Edirisinghe Date: $6^{\text {th }}$ June 2013 5266FM2010 018 
I certify that the above statement made by the candidate is true and that this thesis is suitable for submission to the University for the purpose of evaluation.

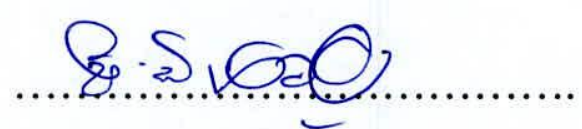

Dr. P. D. Nimal

Date: $6^{\text {th }}$ June 2013

Supervisor 


\section{Table of Content}

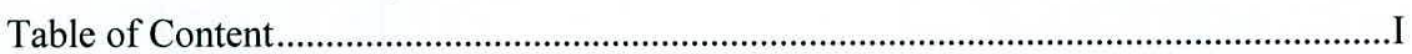

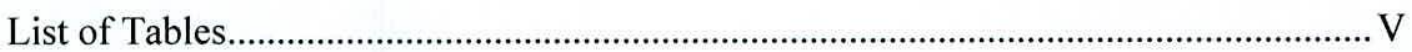

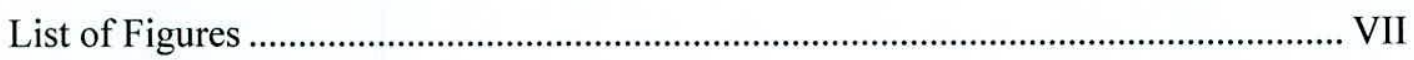

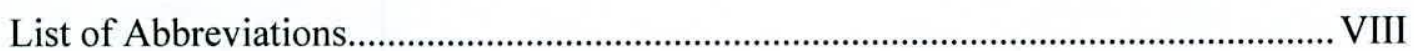

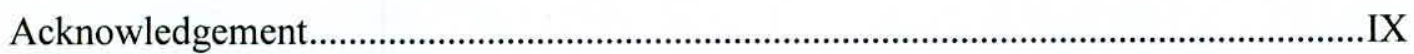

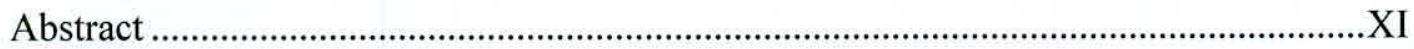

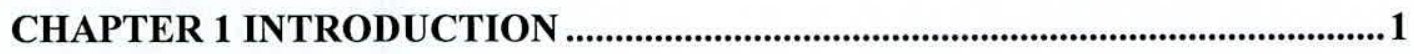

1.1. BACKGROUND OF THE STUDY …................................................................

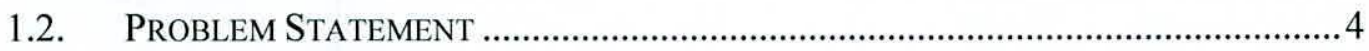

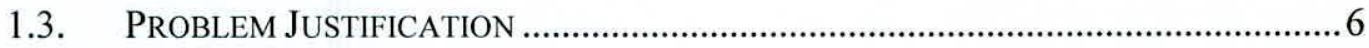

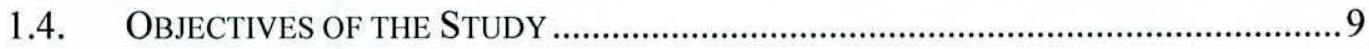

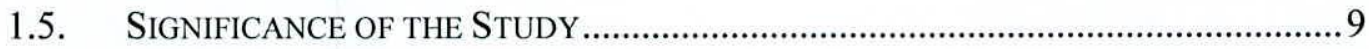

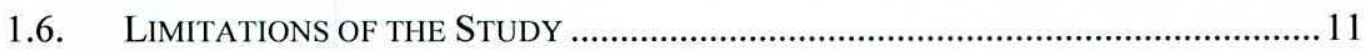

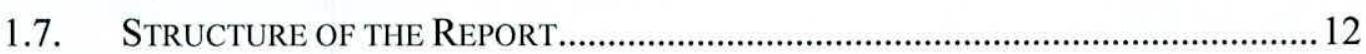

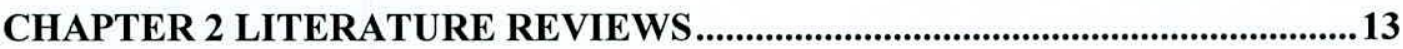

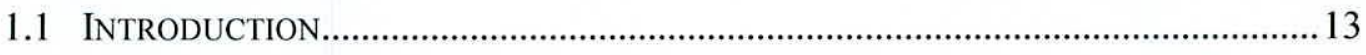

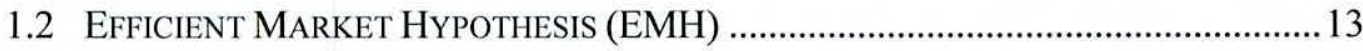

1.2.1 The Weak Form Efficiency ……………..................................................... 14

1.2.2 Semi Strong Form Efficiency ….............................................................. 15 
1.3 Theories Justifying Price Reaction to Security Issue Announcements. 17

1.3.1 The Traditional Trade-off Theory …............................................................17

1.3.2 The Pecking Order Theory .............................................................................. 19

1.3.3 The Dynamic Trade-Off Theory ................................................................22

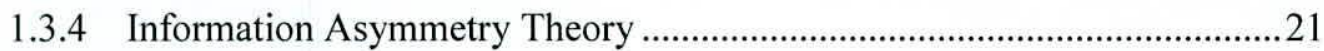

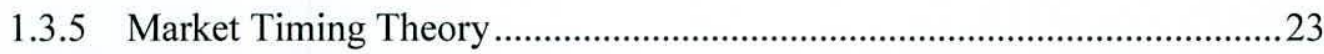

1.4 EMPIRICAL EVIDENCES FOR STOCK MARKET REACTION FOR SECURITY ISSUES ..25

1.4.1 Stock Market Reaction to Right and Seasoned Equity Issue .....................25

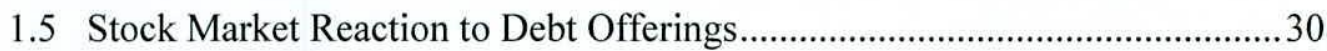

1.6 Theoretical Explanations for Nature of the Stock Price Reactions..................32

1.7 Factors AfFecting Stock Price ReACtion .....................................................4

1.7.1 SIZE OF THE ISSUE/AMOUNT OF FINANCING ................................................4

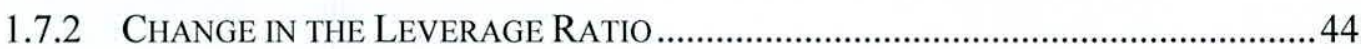

1.7.3 STOCK PRICE PERFORMANCE PRIOR TO OFFERING...............................................46

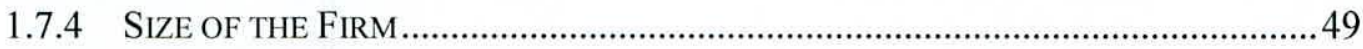

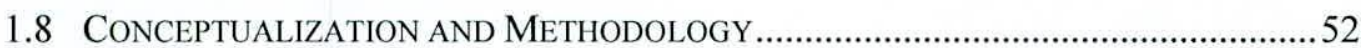

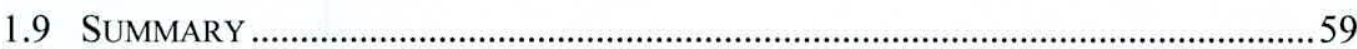

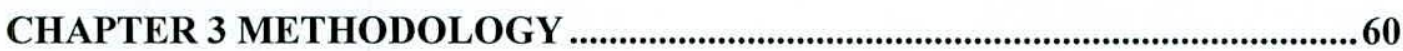

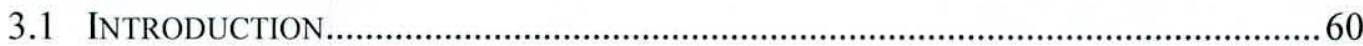

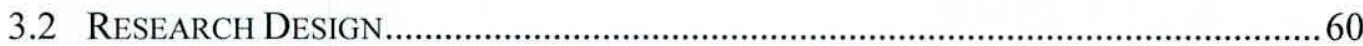

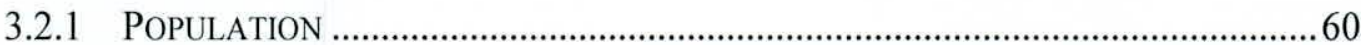




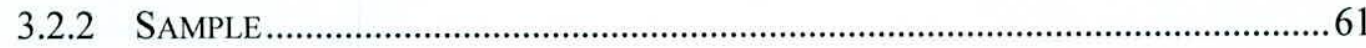

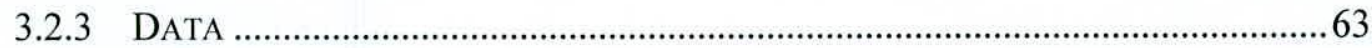

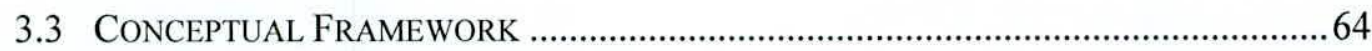

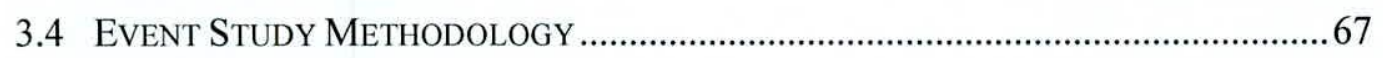

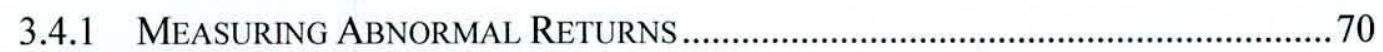

3.4.2 TeST StATISTICS WITH ABNORMAL PERFoRMANCE.............................................73

3.5 Computation OF ACTUAL RETURNS AND NORMAL RETURNS............................... 75

3.5.1 COMPUTATION OF ACTUAL DAILY STOCK RETURNS ….................................... 75

3.5.2 Alternative MethodS OF Modeling Normal RETURn ...............................76

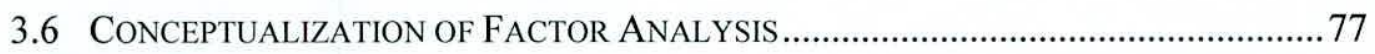

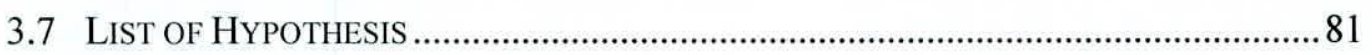

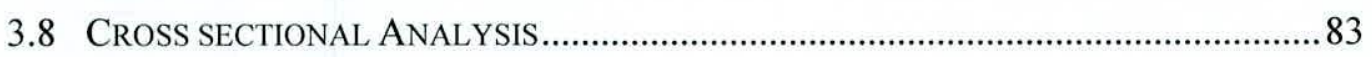

3.8.1 VARIABLE MEASUREMENT FOR FACtOR ANALYSIS..........................................83

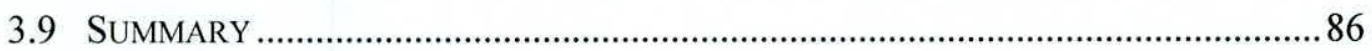

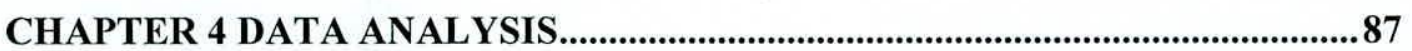

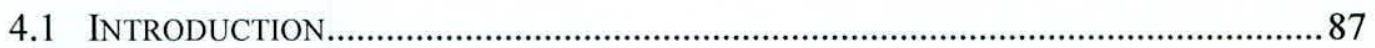

4.2 AAR \& CAAR AROUND ANNOUNCEMENT DATE ACCORDING ALTERNATIVE MODELS 87

4.2.1 ABNORMAL RETURNS ACCORDING TO MAR METHOD......................................87

4.2.2 ABNORMAL RETURNS ACCORDING TO IM METHOD .......................................93

4.2.3 ABNORMAL RETURNS ACCORDING TO CAPM METHOD ..................................99

4.3 CROSS SECTIONAL REgRESSION ANALYSIS OF RIGHT ISSUE ANNOUNCEMENTS........ 104 
4.4 CROSS SECTIONAL REGRESSION ANALYSIS OF DEBENTURE ISSUE ANNOUNCEMENTS



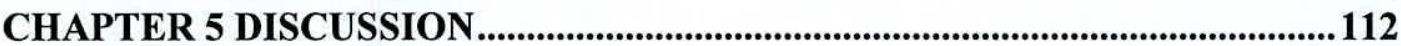

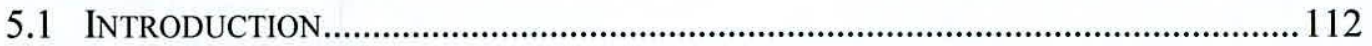

5.2 COMPARISON OF ABNORMAL PERFORMANCE MEASURES AND THEIR COMPARISON . 112

5.3 Discussion ON Study Findings with Previous Litreture

5.4 DiscusSion On PREVIOUS Literature RELATED TO FACTOR AFFECTING FOR PRICE REACTION 124

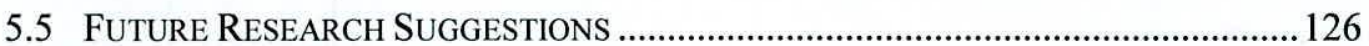

CHAPTER 6 SUMMARY \& CONCLUSION ........................................................128

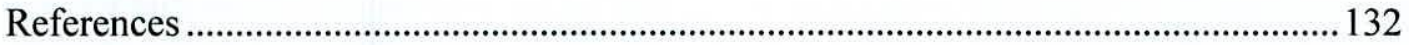

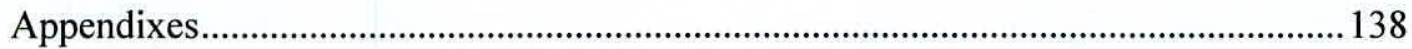




\section{List of Tables}

Table 2.1 Summary of Abnormal Return Results of Previous studies - Right Issues

Table 2.2 Summary of CAAR Results of Previous Studies - Debt Issues

Table 2.3 Literature on Cross Sectional Regression Analysis of Equity Issues 51

Table 3.1 Sample Distribution by Year. 62

Table 4.1AAR and CAAR from 20 days Event window under MAR Method 88

Table 4.2 CAAR to right Issue announcement under MAR method 91

Table 4.3 CAAR to Debenture Issue announcement under MAR method 92

Table 4.4 AAR and CAAR from 20 days Event Window under IM Method 94

Table 4.5 CAAR to right Issue announcement under IM method 96

Table 4.6 CAAR to Debenture Issue announcement under IM method ... 98

Table 4.7 AAR and CAAR from 10 days Event Window under CAPM Method 99

Table 4.8 CAAR to Right Issue announcement under CAPM method 102

Table 4.9 CAAR to Debenture Issue announcement under CAPM method 103

Table 4.10 Results of Cross Sectional Analysis of Right Issues - MAR Model. 104

Table 4.11 Results of Cross Sectional Analysis of Right Issue - IM Model 105 
Table 4.12 Results of Cross Sectional Analysis of Right Issues - CAPM Model 106

Table 4.13 Results of Cross Sectional Analysis of Debenture Issue MAR Model............ 108

Table 4.14 Results of Cross Sectional Analysis of Debenture Issue - IM Model.............. 109

Table 4.15 Results of Cross Sectional Analysis of Debenture Issue - CAPM Model ....... 110

Table 5.1 Comparison of CAAR of Right Issue Announcements

Table 5.2 Comparison of CAAR of Debenture Issue Announcements 117 


\section{List of Figures}

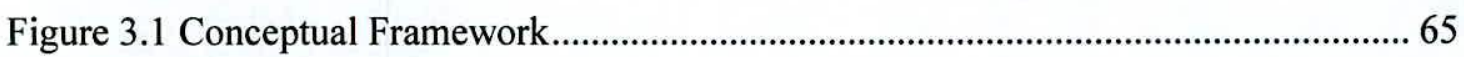

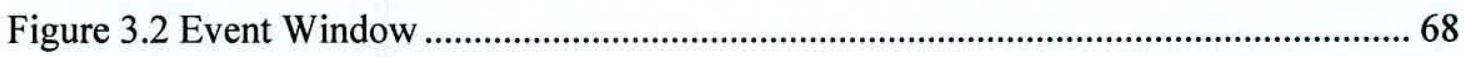

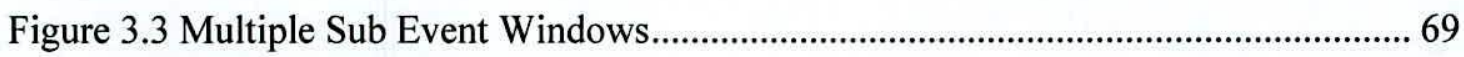

Figure 4.1 Pre and post window AAR behavior under MAR method ................................ 89

Figure 4.5 Pre and post window AAR behavior according to IM method ...........................95

Figure 4.6 Pre and post window CAAR according to CAPM Method .............................. 101

Figure 5.1 Comparison of CAAR of Right Issue Announcements .................................. 115

Figure 5.2 Comparison of CAAR of Debenture Issue Announcements ............................ 119 


\section{List of Abbreviations}

\section{CSE - Colombo Stock Exchange}

SEC - Security and Exchange Commission

MAR - Mean Adjusted Return

IM- Market Adjusted Return

MM - Market Model

CAPM - Capital Asset Pricing Model

ASPI - All Share Price Index

ASTRI - All Share Total Return Index

SEO - Seasonal Equity Offering

DW- Durbin Watson

EW - Event Window 


\section{ACKNOWLEDGEMENT}

Two years of grapple has finally reached to a sign of its destined end, where this note of thanks/acknowledgement comes alongside with a mixture of feelings, where I'm acquainted with a sigh of a relief and a sigh of triumph.

My sincere thanks goes to Dr. P. D. Nimal who has not only been my Supervisor/Mentor/Former Course coordinator, but a highly dependable cobber who transformed this research from a disarranged set of thoughts to a discerning and impregnable piece of work.

If it had not been for the courage, guidance and continues support of Dr. P.J. Kumarasinghe Coordinator Post Graduate Centre for Business Studies, this would have not been a realistic achievement for me. And I am grateful to Prof. Dr. Kennady Gunawardane for building an in-depth knowledge and skills requirement on research methodology which was the solid foundation for this thesis.

I would like to extend my gratitude to entire lecture panel of MPM/MPM/M.Sc. Management Program for nourishing me with due knowledge and temperament to achieve this land mark in my academic career.

I also convey my gratitude to Mr. Nishantha Hewavithana of Colombo Stock Exchange and Ms. P.A. N. S. Anuradha of University of Sri Jayawardanepura for their support during the data collection process. Also I thank my college Mr. Sandun Keerthipala and 
Ms. Janani Kulasekara for the editorial assistance provided and Mr. T.U.I Peiris for the assistance and guidance provided for the statistical analysis.

Finally I would like to thank my endearing parents whose trust in me was one of the greatest strengths I had during this journey to overcome many obstacles and my three sisters, specially the youngest who bore with me for the continues trouble given for the data preparation work and for the two elders for the endless encouragement during challenging time. 


\title{
Stock Price Reaction to Announcements of Right Issues and Debenture Issues: Evidence from Colombo Stock Exchange
}

\author{
Udani Chathurika Edirisinghe
}

\begin{abstract}
This study was carried out to investigate the stock market reaction for right issues and debenture issues of Colombo Stock Exchange (CSE) during the period of 2005 to 2011. In absence of seasonal equity issues in CSE, right issues have been considered as equity issues and debenture issues have been considered as debt issues. During the sample period, 138 right issue announcements and 30 debenture issue announcements were reported, from which only 96 right issue and 20 debenture issue announcements were qualified for the sample. Study Methodology was used to investigate the ex-ante and expost market reactions, for the two types of security announcements while predicting abnormal returns, based on three alternative normal/expected returns modeling methods. Namely Mean Adjusted Model, Market Adjusted Model, and Capital Asset Pricing Model, further, a cross sectional regression analysis was carried out to assess the factors affecting price reaction, around security issue announcements.
\end{abstract}

For right issue announcements listed companies of CSE reacted positively during the 30 days prior to the announcement and started to react negatively from 2 days after the announcements according to all three methods utilised to generate abnormal returns. Though a cumulative abnormal return (CAAR) of the three day event window is 
positive, the CAAR after Day 2 was significantly negative. Market reacted negatively during the period prior to debenture issues and continued to do so during the post event window as well. Though the non-zero CAAR on immediately around announcement day (day $-1,0,+1)$ was not statistically significant, the negative returns of 30 days and 10 days pre and post to the announcement were significant. Again the direction of the price reaction was not significant. Though the magnitude and significance of abnormal return generated through three alternatives normal return modeling methods differs, the pattern of the CAAR of all three models were similar, this confirms the previous findings on multiple model usage. Cross sectional regression analysis reveals a significant positive influence of issue size on price reaction/abnormal returns of issuing firm and significant negative impact of pre offer leverage ratio on price reaction/abnormal returns of the issuing firm. Finally the analysis reveals that CSE is not efficient in semi strong form sense 